\title{
Factors Affecting the Performance of Medium and Large Local Contractors in the Jigawa State Nigerian Construction Industry
}

\author{
Md Asrul Nasid Masrom ${ }^{1, *}$, Garba Hamza $^{2}$, Norpadzlihatun Manap ${ }^{1}$ and Noor Shahifah Syahrom ${ }^{1}$ \\ ${ }^{1}$ Department of Construction Management, Faculty of Technology Management and Business, Universiti Tun Hussein Onn Malaysia, \\ 86400 Parit Raja, Batu Pahat, Johor, Malaysia \\ ${ }^{2}$ Ministry of Education Science and Technology, Dutse, Jigawa State, Nigeria
}

\begin{abstract}
Medium and large local contractors in the Nigerian construction industry suffer from numerous problems and complex issues in regards to their performance in executing projects, particularly cost, time and quality. This paper is to identify the factors affecting the performance of medium and large local contractors in the Jigawa state Nigerian construction industry. Literature about medium and large local contractors, their performance was reviewed to identify the factors believed to affect their performance in executing construction projects. One hundred thirty-six questionnaires distributed to clients, consultants, medium and large local contractors. The findings indicate that all the respondents agree that the most significant factors affecting the performance of medium and large local contractors in the Jigawa state Nigerian construction industry were corruption, the time taken in payment from the client to contractor, additional work given during construction, used of an unskilled labour force and non-adherence to specification. This paper helps to expand the pool of knowledge to the Nigerian contractors regarding essential element that is needed to be observed in order to improve their performance.
\end{abstract}

\section{Introduction}

The construction industry plays a significant role in the economy of developing countries. In many developing countries, main construction activities account for about $80 \%$ of the total capital assets, $10 \%$ of their Gross Domestic Product (GDP), and more than 50\% of the wealth invested in fixed assets. In addition, the industry provides high employment opportunity, probably next after agriculture [1]. Similarly, Nigeria with a population of over 179 million people and Africa's largest economy as at 2014 after its Gross Domestic Product (GDP) was rebased in 2013 to stand at N82.2 trillion (US\$510 billion) (World Population Review, 2014). Its construction industry provides only three $(3 \%)$ percent of the nation's (GDP) Gross Domestic Product [2].

In developing countries, problems associated with performance are higher and even compounded due to its inadequate resources and organizations to address them $[3,4,5,6,7,8,29,30,31]$. In Nigeria, the construction industry is vibrant and the largest in Africa [5]. Based on the literature review, it shows that there are factors accountable for medium and large local contractors' poor performance. As such, the objective of this paper is to investigate the factors responsible for this poor performance of (medium and large) local contractors' in the Jigawa state Nigerian construction industry. This is, in turn, will offer better performance and also will expand the pool of knowledge to the Nigerian contractors regarding essential element that is needed to be observed in order to improve their performance.

\section{Methodology}

Findings from the literature reviewed form the bases for drafting the questionnaire $[10,11,12,13]$. The questionnaire was sent out for a pilot test to ensure that the questions provide required data undoubtedly. A structured questionnaire sent to the target respondents which lead an investigation of factors affecting the performance of medium and large local contractors in Jigawa state Nigerian construction industry. Data collected in a standardized form from samples of the population. The standardized form allows the researcher to carry out statistical inferences on the data, often with the help of the computer.

A questionnaire survey conducted the respondents were asked to indicate based on their local experience, the level of importance of each one of the identified factors. Twenty-seven factors were identified and categorized into five groups, evaluated and ranked from the client, consultants, and medium and local contractor's perspectives. One hundred thirty-six questionnaires distributed as follows: 21 to clients, 25 to consultants, 45 to medium and large contractors each. One hundred

\footnotetext{
* Corresponding author: padzliha@uthm.edu.my
} 
nineteen questionnaires were received (87.5\%) as follows: $(85.7 \%)$ from clients, $(80 \%)$ from consultants and $(90 \%)$ from both local contractors as respondents. The respondents comprised of an experienced client, consultants, and local (medium and large) contractors (with an average experience of 20 years in the construction industry). 27 factors believed to affect medium and large local contractors' performance were considered in this study and listed under five groups based on the literature reviewed.

\section{Results and discussion}

\subsection{Factors affecting the performance of (medium and large) local contractors'}

Questionnaire was divided into six main sections, which include; (i) Profile of respondent, (ii) cost factor affecting the performance of (medium and large) local contractors; (iii) time factor affecting the performance of (medium and large) local contractors; (iv) quality factor as affecting the performance of (medium and large) local contractors; (v) re-design and re-work factor affecting the performance of (medium and large) local contractors; (vi) political factor affecting the performance of (medium and large) local contractors. Data collected were analysed using both descriptive and inferential tools of statistical software Statistical Package for Social Science (SPSS 2.0).

\subsection{Most significant, moderate and least factors affecting the performance of (medium and large) local contractors'}

Table 1 indicates the first five (5) most significant factors affecting the (medium and large) local contractors' performance in the Jigawa state Nigerian construction industry according to the respondents' perception are corruption, time taken in payment from client to contractor, additional work given during construction, used of unskilled labour force and non adherence to specification in construction projects.

The respondents indicated that corruption is the first most significant factor with the highest mean value of 4.53 which can manifest in many related forms. Corruption can occur at any stage of a construction project, and the result indicates that it affects the performance of (medium and large) local contractors in the Jigawa state Nigerian construction industry. The result supported by several pieces of research conducted in the construction industry despite the differences in location and period of the research. $[12,14,15,16]$. This indicates that corruption is a critical issue that (medium and large) contractors should bother a lot to avoid.

The second most significant factor indicated by the respondents is time taken in payment from the client to the contractor, which is having the mean of 4.26. The respondents agreed that this also has a significant effect on the (medium and large) local contractor. This factor has a severe effect because any delay in payment from the client will affect payment to diverse workforces and it will cause a delay in the entire project. This will affect the general performance of the project. The result is in agreement with the work of Dada (2000) despite the variances in locality and period of the research [17].

The third most significant factor affecting the performance of both medium and large contractors in the Jigawa state Nigerian construction industry is the additional works giving during construction with a mean of 4.24. The result is in agreement with the work of $[18,19]$. The extended time required for full implementation of changes stands in contrast to the tight schedule that is often pursued by the contractor, which at the end affect the performance of the (medium and large) local contractor.

The fourth most significant factor affecting the performance of the (medium and large) local contractor in the Jigawa state Nigerian construction industry, with the mean of 4.16 used of the unskilled labour force. Used of unskilled labour increase employment instability, decrease general human capital of workers and affect the performance of local contractors in the Jigawa state Nigerian construction industry. The work of [20,21] has supported the result. This indicates that (medium and large) local contractors should avoid using unskilled labour force in the Jigawa state Nigerian construction industry.

The fifth most significant factor affecting the performance of (medium and large) local contractors in the Jigawa state Nigerian construction industry is Nonadherence to specification, having the mean of 4.13. Adherence to specification is an important aspect which is required to be observed in every aspect of the project. Non-adherence to specification affects the project life cycle, in the end, it will affect the general performance of (medium and large) local contractors in the Jigawa state Nigerian construction industry. This result contradicts the work of $[11,22]$. This is because of differences in the location and the periods of the researches conducted. More so, this research considers only medium and large contractors as respondents, not the contractors in general.

Table 1. Mean values and ranking for factors 


\begin{tabular}{|c|c|c|}
\hline $\begin{array}{l}\text { Factors affecting the performance of } \\
\text { medium and large local contractors }\end{array}$ & Mean & Ranking \\
\hline \\
\hline Corruption & 4.53 & 1 \\
\hline $\begin{array}{l}\text { Time taken in payment from the client } \\
\text { to contractor }\end{array}$ & 4.26 & 2 \\
\hline $\begin{array}{l}\text { Additional work gave during } \\
\text { construction }\end{array}$ & 4.24 & 3 \\
\hline Used of an unskilled labour force & 4.16 & 4 \\
\hline Non-adherence to specification & 4.13 & 5 \\
\hline \multicolumn{3}{|l|}{ Moderate factors } \\
\hline Project cash flow & 3.98 & 6 \\
\hline The high cost of labour & 3.92 & 7 \\
\hline unpredictable shifts in the economy & 3.87 & 8 \\
\hline $\begin{array}{l}\text { unexpected changes in consumer } \\
\text { demand }\end{array}$ & 3.82 & 9 \\
\hline $\begin{array}{l}\text { Engineer-to-order (ETO) products late } \\
\text { delivery }\end{array}$ & 3.79 & 10 \\
\hline \multicolumn{3}{|l|}{ Least factors } \\
\hline Site preparation time & 2.20 & 25 \\
\hline Poorly mixed ratio & 2.19 & 26 \\
\hline Cost of variation orders & 2.19 & 27 \\
\hline Average Mean & 3.45 & \\
\hline
\end{tabular}

The moderate significant factors affecting the performance of medium and large local contractors in the Jigawa state Nigerian construction industry as indicated by the respondents include; Project cash flow, High cost of labour and unpredictable shifts in the economy. These factors were ranked in mean in as 3.98 , 3.92 and 3.87 respectively.

Furthermore, unexpected changes in consumer demand, engineer-to-order (ETO) products late delivery, changes in government policy were ranked 3.82 and 3.79 respectively. Table 1 also indicated that the first least significant factor affecting the performance of the (medium and large) local contractor in the Jigawa state Nigerian construction industry is Site preparation time, with the mean of 2.20. However, the respondents disagree that site preparation time affects the performance of local contractors in the Jigawa state Nigerian construction industry. This result contradicts the work of [19] due to the difference in the period of the researches and also due to the current use of technological tools and equipment on site.

The second least significant factor affecting the performance of the (medium and large) local contractor in the Jigawa state Nigerian construction industry is poorly mixed ratio also been indicated by respondents as having mean of 2.19 and was ranked twenty-six (26) in the mean values and ranking. However, respondents disagree that poorly mixed ratio affect the performance of (medium and large) local contractors in the Jigawa state Nigerian construction industry, this may be due to the current use of technological tools and equipment by the contractors. However, this contradicts the work of [23] indicating that the mixed ratio affects contractors performance. This may be due to differences in period and location of the researches.

The third least significant factor affecting the performance of the (medium and large) local contractor in the Jigawa state Nigerian construction industry is the cost of variation order which also has a mean of 2.19. It causes deviations from client objectives such as the cost of the project, the date of completion and the performance requirements. This result is in agreement with the work of $[18,24]$ despite the differences in location and period of the research. Cost is needed to implement variation orders and will affect the performance of the basic schedule, which is an addition of time, and it affects the performance of (medium and large) local contractors.

\subsection{Factors Aggregate mean and Ranking According to all Categories}

Table 2 shows the categories of factors affecting the performance of the (medium and large) local contractor in the Jigawa state Nigerian construction industry. Based on the responses from the respondents indicates that the most significant factor according to all categories, is the political factor with aggregate mean of 3.76, this shows that at categories level political factor is the most significant factor affecting the performance of the (medium and large) local contractors in the Jigawa state Nigerian construction industry. As there is no project exists in a vacuum but instead subject to an array of influences from regulatory control to political and industrial intervention and opined that managers of the construction project will take cognisance of the political aspect that can produce an uncertain environment such as unstable government, corruption, unpredictable shifts in the economy and unexpected changes in consumer demand, which at the end affect the performance of (medium and large) local contractor.

The second significant factor that most affect the performance of (medium and large) local contractor according to all categories, based on the response from the respondents is the re-design and re-work which has a mean aggregate of 3.56. This result is in line with the work of $[11,24]$. As re-design and rework are to conform to the original requirements by completion or alteration, it continues to affect both cost and schedule performance throughout the construction project, which at last will affect the performance of the (medium and large) local contractor.

The average factor according to the aggregate Table 2 below, which affects the performance of (medium and large) local contractors in the Jigawa state Nigerian construction industry, is the quality factor with the mean aggregate of 3.46. It is in agreement with the work of $[11,25]$ the traditional project performance measures of cost, time and quality are frequently used to measure contractors' performance by clients.

Table 2. Factors affecting performance

\begin{tabular}{|c|c|c|}
\hline Factors & Aggregate Mean & Ranking \\
\hline Cost & 3.25 & 4 \\
\hline Time & 3.21 & 5 \\
\hline Quality & 3.46 & 3 \\
\hline Re-Design/Work & 3.56 & 2 \\
\hline Political & 3.76 & 1 \\
\hline
\end{tabular}


Furthermore, cost factor also emerges as the second to the least factors and is having the mean aggregate of 3.25 . This result is in line with the work of [26,27]. Traditional project performance control is usually generic (cost control techniques).

Lastly, the time factor which has the least effect on (medium and large) local contractor performance as indicated by the responses of the respondents, it has an aggregate mean of 3.21. This is in line with the work of $[25,28]$. Any delay in the execution of the project affects the whole construction process; nevertheless, the time factor is the least among all the factors that affect (medium and large) local contractors as indicated in Table 1.

\section{Conclusion and recommendations}

The construction industry is an essential industry in national development; it develops and achieves the goals of society. The performance of the local contractor is affected by the following cost, time, re-design and rework political, quality and other factors. This research aims to identify factors affecting the performance of medium and large local contractors in the Jigawa state Nigerian construction industry. A structured questionnaire survey approaches considered, the questionnaire assists in studying the perception of contractors, consultants, and clients. Twenty-seven (27) factors were considered in this research and listed under five (5) groups based on literature review, which are; cost, time, quality, re-design, rework and political. These groups give a comprehensive summary of the main factors affecting performance. The factors were summarized and collected according to the previous studies and recommendation by experts.

The questionnaire was sent to various potential respondents to disclose their opinions on the factors affecting the performance of medium and large local contractors in the Jigawa state Nigerian construction industry. Five (5) most significant factors were confirmed based on their mean values. These are corruption, the time taken in payment from the client to contractor, additional work given during construction, used of the unskilled labour force and non-adherence to specification in construction projects. These are the most significant factors identified, and the results are in agreement with the work of $[16,18,22]$ however, on a different research location, area, and country, this may be due to both pieces of research were conducted in developing countries. This result contradicts the results of Velmurugan and Srithar, (2011); Hazmi, (2009) and Assaf et al. (2006) may be due to differences in locations and periods the studies conducted.

The authors recommended that Government should come up with an effective mechanism to ensure transparent bidding process, to overcome the issue of corruption, delay and cost problems. Furthermore, renewable and non-renewable resources should develop in the Nigerian construction industry, through quality training and meetings In order to update knowledge and assist with project management processes and techniques, for construction projects performance. Clients are recommended to facilitate payment to contractors to overcome delay, disputes, and claims. Stakeholders in the construction industry must ensure efforts to achieve the required level of quality for a product which is well planned and organized. Maintaining the quality of construction works at the required standard will obtain customers' satisfaction, this, in turn, would bring long-term competitiveness and business survival for the industries. Contractors should consider risk assessment in their cost estimation in order to adhere to project specifications in order to overcome delay, disputes, and performance problems of time and cost.

Moreover, Contractors should also adhere to the use of quality materials to improve cost, time, and quality performance and should avoid taking too many projects that cannot be executed successfully. Furthermore, they should also adhere to the sequencing of work according to schedule and have a cost engineer in their projects to control cost successfully. Consultants are recommended to facilitate and quicken orders delivered to contractors to obtain better time performance and to minimize disputes and claims. Sensitive and critical decision-making, continuous coordination and relationship between project participants required through the project life cycle for solving problems and developing project performance.

This research was performed to fulfill the requirements of a research grant (Vote no. R063). Acknowledgments are given to the Ministry of Higher Education Malaysia and the Office for Research, Innovation, Commercialization and Consultancy Management, Universiti Tun Hussein Onn Malaysia for their support during the publication of this paper.

\section{References}

1. A. H. Yimam, University of Maryland College Park (2011).

2. I. T. Terwase, A. N. Abdul-Talib and K. T. Zengeni (2014).

3. S. Gushibet, Jos Journal of Economics, 4(I) (2012).

4. N. Manap, Y.K. Goh and N. Syahrom, IOP Conference Series: Earth and Environmental Science, 109, 012008 (2017)

5. N. Manap, N.H. Mohd Noh and N. Syahrom, IOP Conference Series: Earth and Environmental Science, 109, 012011 (2017)

6. N. Manap and N. Voulvoulis, Applied Mechanics and Materials, 567, pp. 50-55 (2014)

7. N. Manap, K.Y. Tan and N. Shahrom, IOP Conference Series: Earth and Environmental Science, 109, 012026 (2017)

8. N. Manap, N.I. Muhamad and K. Sandirasegaran, Materials Science Forum, 889 261-264(2017)

9. I.I. Inuwa, G. Wanyona, and S. Diang'a, (2015). African Journal of Applied Research 1(1) 
10. B. Mafimidiwo and R., Iyagba, Journal of Emerging Trends in Economics and Management Sciences 6(2) 101-109(2015).

11. K. Bala, A. Bello, B. A. Kolo, and S. A. Bustani, Procs 25th ARCOM Conference, 7-9 Sept. 2009, Nottingham U.K.: ARCOM 351-359

12. D.A. Muazu and S. A. A. Bustani, ATBU Journal of Environmental Technology, 3(1) 13-16 (2004),

13. M. Sohail, S. Cavill. Journal of Construction Engineering and Management 134(9) 729738(2008)

14. C.Kenny, Transport Reviews: A Transnational Transdisciplinary Journal 29(1) 21-41(2009).

15. Y.Le M.Shan, A.Chan, H. Yi, Journal of Management in Engineering 30(4) 1-7(2014).

16. M. O. Dada and B. U. Akpadiaha, International Journal of Architecture, Engineering and Construction 1(2) 103-111(2012)

17. S.Isaacand and R. Navon, Automation in Construction, 31 31-40(2013).

18. R.B. Isa, R. A. Jimoh, and E. Achuenu, Net Journal of Business Management 1(1) 1-6(2013).

19. S. Blasco, B. Crépon and T. Kamionka, The Effects of On-the-job and Out-of-Employment Training Programmes on Labour Market Histories (No. 1210). CEPREMAP(2012).

20. D. Arditi, A. Elhassan, and Y. C. Toklu, Journal of Construction Engineering and Management, 128(2) 117-126 (2002).

21. D. I. Ikediashi, A. Mendie, E. Achuenu and M. G. Oladokun, Journal of Human Ecology 37(1) 37-46 (2013)

22. I. O. Famakin, O. I .Aje and D. R. Ogunsemi, Journal of Financial Management of Property and Construction 17(2) 153-165(2012).

23. P. E. D. Love, J. Constr. Eng. Manage 128(1) 1829(2002).

24. S. Okunlola Ojo, O. Aina, and A. Yakeen Adeyemi, Journal of Civil Engineering and Management 17(2) 227-233(2011).

25. P. Muchiri, L. Pintelon, L. Gelders and H. Martin, International Journal of Production Economics 131(1) 295-302(2011).

26. I. Nahum-Shani, M. Qian, D. Almirall, W. E. Pelham, B. Gnagy, G. A. Fabiano and S. A. Murphy, Psychological Methods 17(4) 478 (2012).

27. M. E. Juliet and O. E. Ruth, An Evaluation of Factors Affecting the Performance of Construction Projects in Niger State(2014).

28. N. Manap, R.A.A., Raja Bedali, K. Sandirasegaran, M.A.N. Masrom, and M.Y. Yahya, Jurnal Teknologi, 78(3), pp. 87-92 (2016)

29. K. Sandirasegaran and N. Manap, Jurnal Teknologi, 73(3): 139-143.(2016)
30. N. Manap, S. Polis, K. Sandirasegaran, M.A.N. Masrom, K.C. Goh, and M.Y. Yahya, Jurnal Teknologi, 78(3), pp. 111-116 (2016) 